\title{
Maintenance and Testing of Fume Cupboard
}

\author{
Falah H. Hussein"1, Wedad H. Al-Dahhan², Ali Jassim Al-Zuhairi' ${ }^{3}$, Kabrena E. Rodda4, \\ Emad Yousif ${ }^{2}$
}

${ }^{1}$ College of Pharmacy, Babylon University, Babylon, Iraq

${ }^{2}$ Department of Chemistry, College of Science, Al-Nahrain University, Baghdad, Iraq

${ }^{3}$ College of Engineering, Al-Musayab, Babylon University, Babylon, Iraq

${ }^{4}$ Pacific Northwest National Laboratory, Richland, WA, USA

Email: alijassim33@yahoo.com

How to cite this paper: Hussein, F.H., Al-Dahhan, W.H., Al-Zuhairi, A.J., Rodda, K.E. and Yousif, E. (2017) Maintenance and Testing of Fume Cupboard. Open Journal of Safety Science and Technology, 7, 69-75.

https://doi.org/10.4236/ojsst.2017.71006

Received: October 1, 2016

Accepted: March 28, 2017

Published: March 31, 2017

Copyright $\odot 2017$ by authors and Scientific Research Publishing Inc. This work is licensed under the Creative Commons Attribution International License (CC BY 4.0).

http://creativecommons.org/licenses/by/4.0/

\begin{abstract}
Scientists at universities across Iraq are actively working to report actual incidents and accidents occurring in their laboratories, as well as structural improvements made to improve safety and security, to raise awareness and encourage openness, leading to widespread adoption of robust Chemical Safety and Security (CSS) practices. This manuscript highlights the importance of periodic maintenance on fume cupboards, and is the fourth in a series of five case studies describing laboratory incidents, accidents, and laboratory improvements. In this study, we describe a situation in which the ventilation capacity of the fume cupboard in the undergraduate chemistry laboratories at Al-Nahrain University had decreased to an unacceptable level. The CSS Committee investigated and found the ducting system had been blocked by plastic sheets and dead birds. All the ducts have since been cleaned, and four extra ventilation fans have been installed to further increase ventilation capacity. By openly sharing what happened along with the lessons learned from the accident, we hope to minimize the possibility of another researcher being injured in a similar incident in the future.
\end{abstract}

\section{Keywords}

Science Laboratory, Chemistry Laboratory, Scientific Practical Skills, Fume Cupboard

\section{Introduction}

Fume cupboards are installed in laboratories to protect workers from exposure to hazardous respirable substances. Fume cupboards used for work with harmful substances must meet established engineering standards, such as those outlined in the Control of Substances Hazardous to Health Regulations 2002 [1]. 
In 2014, staff in the Chemistry Department at Al-Nahrain University observed that the ventilation capacity of the fume cupboards in the undergraduate chemistry laboratories had decreased to an unacceptable level. The university's CSS Committee inspected the fume cupboard, ducting and dispersal system outside the building and discovered that the ducting system had been blocked by plastic sheets and dead birds. The CSS Committee's findings and associated lessons learned regarding proper preventive maintenance procedures are summarized in this manuscript in order to minimize the possibility of similar ventilation problems at other university laboratories in the future.

\section{Incident Description}

Where a fume cupboard is not fitted with a built-in airflow velocity meter, or alarm, the bottom of the fume cupboard sashes should be fitted with a strip of flexible material such as plastic tape to indicate when the fume cupboard is drawing in air. Since one-piece ducting systems could not be purchased for this laboratory. Therefore, it was necessary to join one piece of duct with another using a strip of flexible material. Sheets of plastic were used for this purpose.

Over time, the fume cupboards' face velocity appeared to gradually decline, as evidenced by lack of movement from the strip of plastic tape on the bottom of the fume cupboard sash. Eventually, it was determined that the fume cupboards' ventilation capacity had decreased to an unacceptable level. The problem was reported to the university's CSS Committee and the Committee was asked to investigate the source of the problem.

\section{CSS Committee Findings}

The CSS Committee checked the average face velocity on the fume cupboards and determined it to be $0.1 \mathrm{~m} / \mathrm{s}$, which is far below what most universities have come to see as the minimum standard of $0.5 \mathrm{~m} / \mathrm{s}$ at a $500 \mathrm{~mm}$ sash opening [2] [3].

The investigation also revealed that all vertical exhaust stacks discharged exhaust at a height of less than five feet above the roof. Additionally, a white substance precipitated onto the internal surfaces of the ductwork, as shown in Figure 1.

The investigation also revealed the accumulation of a plastic sheet that had been used to join the ducts (Figure 2). After this discovery, all plastic materials were removed, and Teflon tape, which is highly acid-resistant, is now used instead to join the ducts.

The CSS Committee's last finding was that some of the discharge stacks were not fitted with barriers (Figures 3-5). As a result, many dead birds were found stuck inside the ducts (Figure 6 and Figure 7), leading to partially blocked ducts. Since this discovery, the dead birds have been removed (Figure 8) and new barriers have been supplied with the fan sets.

Since the CSS Committee completed its investigation, a set of fans have been installed on the end of the ducts to increase suction efficiency. In accordance 
with system specifications, the fan motor was installed outside the airstream to prevent the transmission of sparks to any potentially explosive fumes (Figure 9).

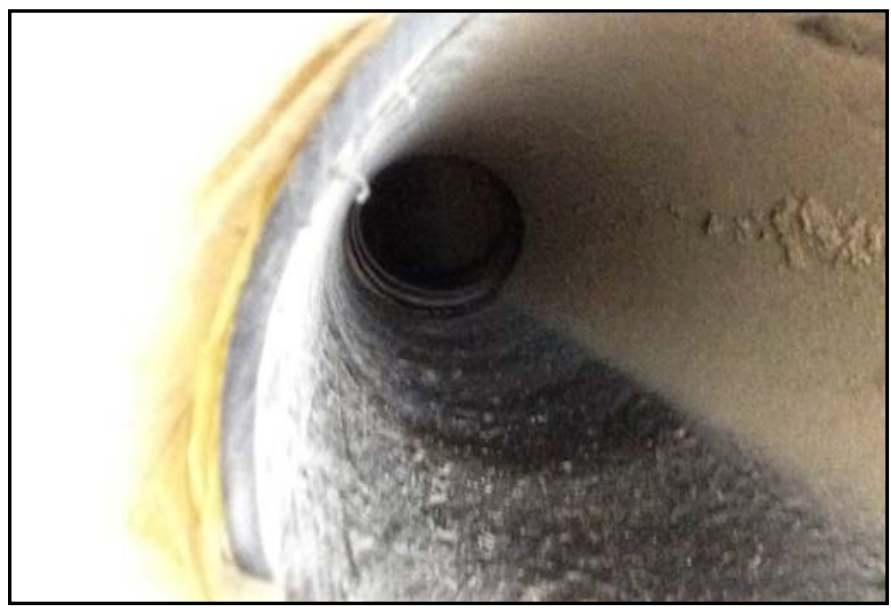

Figure 1. A white substance precipitated onto the internal surface of the ductwork.

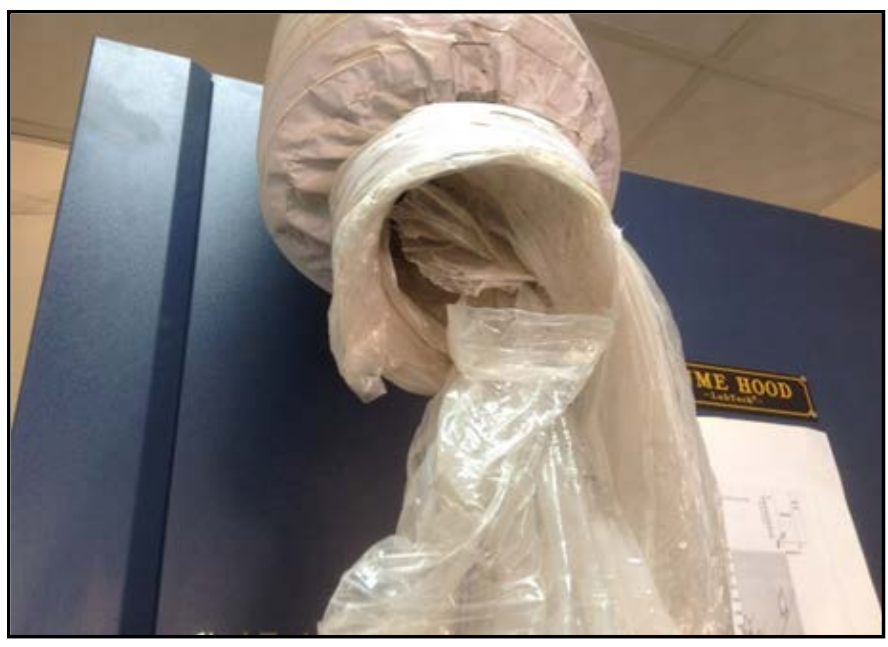

Figure 2. Plastic sheets were found inside the ducts.

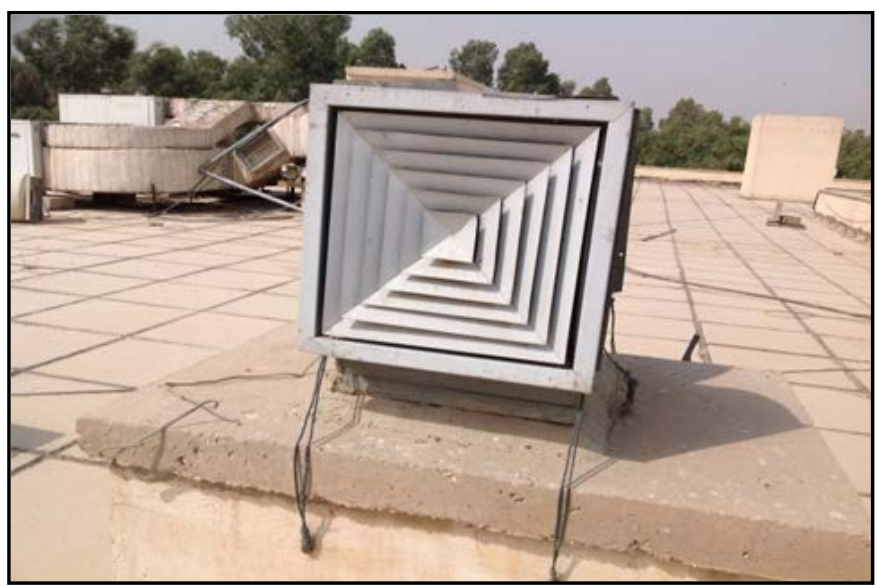

Figure 3. A discharge stack that had been fitted with a barrier. 


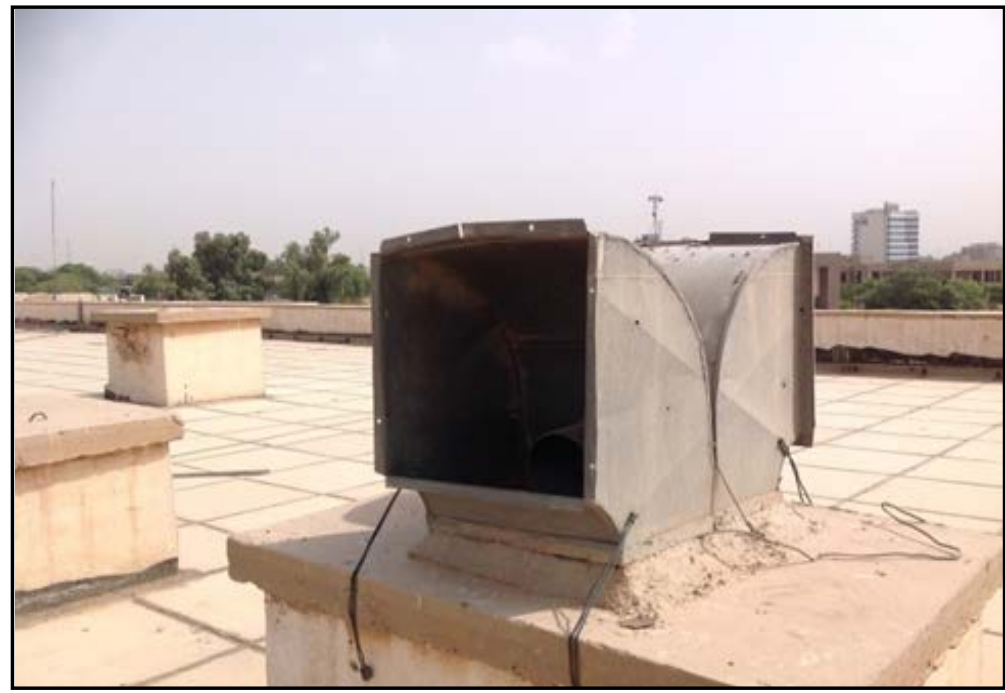

Figure 4. A duct which was not fitted with a barrier.

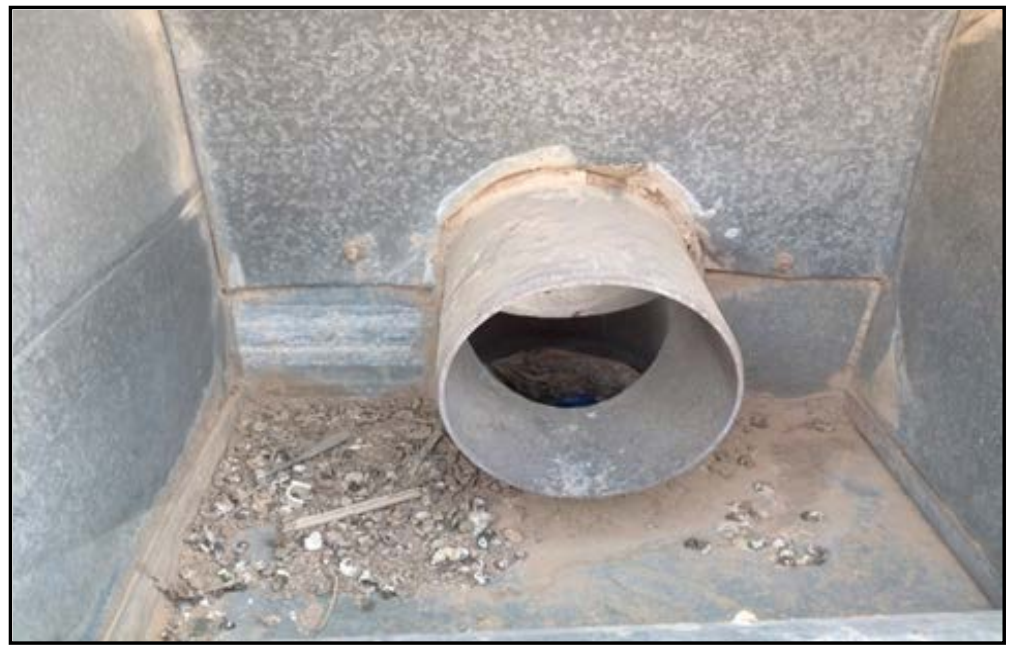

Figure 5. Another duct not fitted with a barrier.

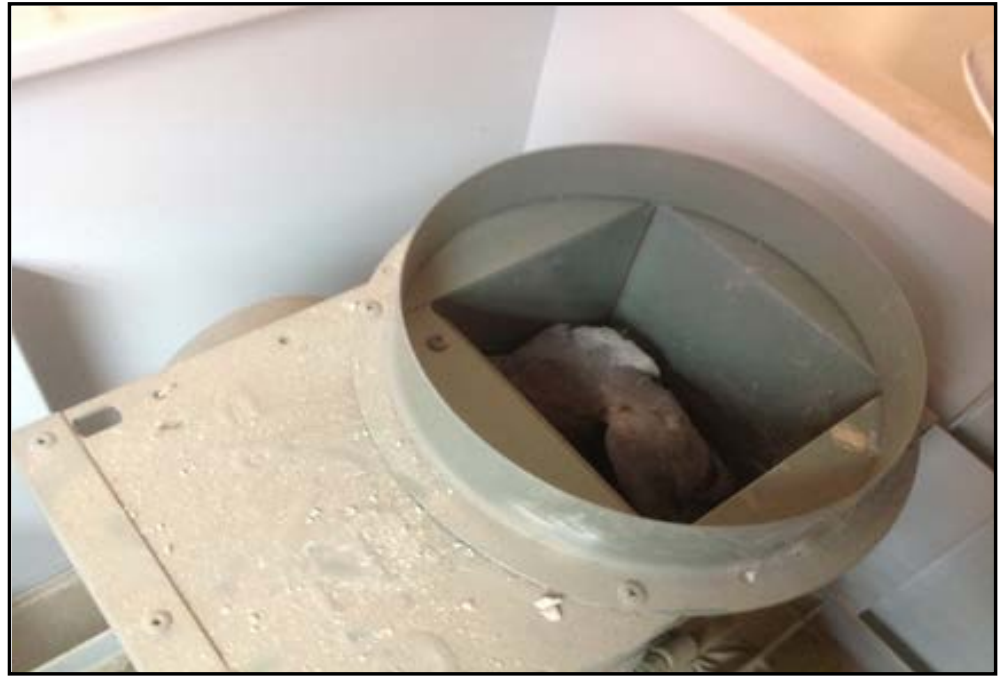

Figure 6. Dead birds were found in some of the fan casings. 


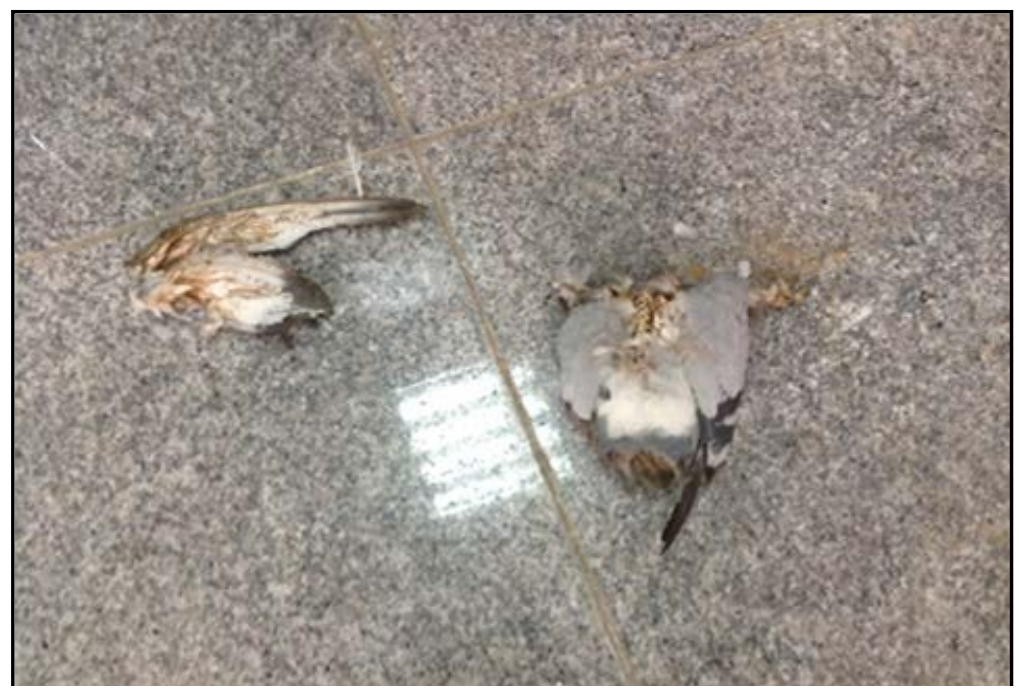

Figure 7. Dead birds found stuck inside the ducts.

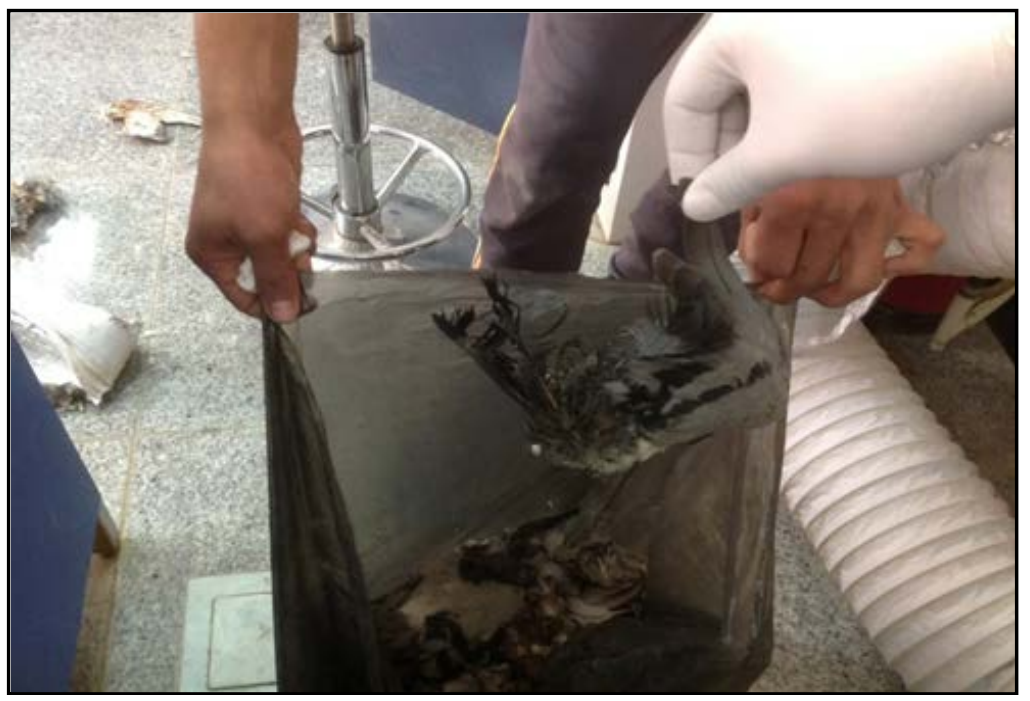

Figure 8. Cleaning dead birds out of the ducting system.

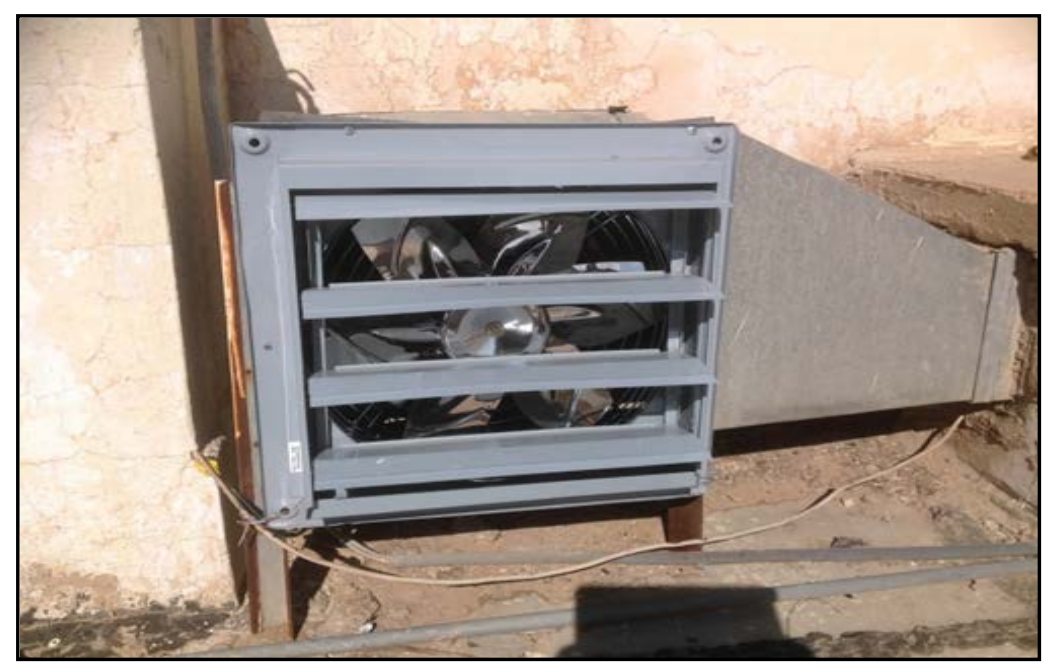

Figure 9. A set of fans have been installed at the end of the ducts. 


\section{Lessons Learned}

In addition to identifying the root cause of the degraded fume cupboard ventilation capacity, this manuscript highlights the following lessons, which are worth noting to minimize the chance of similar problems at other institutions in the future:

1) No work should be carried out in a cupboard which has not been subject to a thorough examination and performance test within the last twelve months. A label should be displayed on each cupboard indicating when the last test was carried out.

2) Exhaust stacks should discharge vertically at a height of no less than three meters from roof level. The stack should incorporate a conical accelerator to increase discharge velocity and assist in fume dispersal.

3) Fumes should discharge above the roof, with care to avoid re-capture through natural ventilation such as through windows, or other air-intake methods.

4) Where fume cupboard discharge points on roofs are likely to expose maintenance workers (or others staff), standard operating procedures should be modified to prevent or minimize exposure to hazardous effluents.

5) The fan motor should be situated outside the airstream to prevent the transmission of sparks to any potentially explosive fumes.

6) Fan sets and associated equipment mounted outside the building at the roof level should incorporate barriers to prevent birds or other items from getting into the ductwork.

\section{Conclusion}

The gradual degradation of ventilation capacity that occurred in the situation described in this manuscript could have been easily avoided through regular routine maintenance of the fume cupboards. By applying the lessons outlined above, institutions can anticipate many years of maximum ventilation capacity for each installed fume cupboard. It is our sincere hope that researchers at other universities will review the lessons summarized here and implement appropriate preventive measures.

\section{Acknowledgements}

The authors acknowledge the staff of the US State Department's Chemical Security Program, Pacific Northwest National Laboratory, Al-Nahrain University and Babylon University for their support and encouragement.

\section{References}

[1] The Control of Substances Hazardous to Health Regulations 1999 and Approved Code of Practice HSE Books 1999. (These Regulations Are Scheduled for Revision in 2002). http://www.hse.gov.uk/pUbns/priced/15.pdf

[2] Guidance on Laboratory Fume Cupboards, the Royal Society of Chemistry, 1990. https://books.google.iq/books/about/Guidance_on_Laboratory_Fume_Cupboards.h tml?id=lUePkQEACAAJ\&redir_esc $=y$ 
[3] Hughes, D. (2010) A Literature Survey and Design Study of Fume Cupboards and Fume-Dispersal Systems. Annals of Occupational Hygiene, 54, 1-4.

ftp://ftp.cdc.gov/pub/Documents/OEL/12.\%20Niemeier/References/Ogden_2010_A nn\%20Occup $\% 20 H y g \% 2054 \% 20-\% 201 \% 20$ p1-4.pdf

Submit or recommend next manuscript to SCIRP and we will provide best service for you:

Accepting pre-submission inquiries through Email, Facebook, LinkedIn, Twitter, etc. A wide selection of journals (inclusive of 9 subjects, more than 200 journals)

Providing 24-hour high-quality service

User-friendly online submission system

Fair and swift peer-review system

Efficient typesetting and proofreading procedure

Display of the result of downloads and visits, as well as the number of cited articles

Maximum dissemination of your research work

Submit your manuscript at: http://papersubmission.scirp.org/

Or contact ojsst@scirp.org 